Meta

Journal des traducteurs

Translators' Journal

\title{
Scientific Terminology in the Arab World: Production, Co-ordination, and Dissemination
}

\section{Mahmoud Esmail Sieny}

Volume 30, numéro 2, juin 1985

URI : https://id.erudit.org/iderudit/004142ar

DOI : https://doi.org/10.7202/004142ar

Aller au sommaire du numéro

Éditeur(s)

Les Presses de l'Université de Montréal

ISSN

0026-0452 (imprimé)

1492-1421 (numérique)

Découvrir la revue

Citer cet article

Sieny, M. E. (1985). Scientific Terminology in the Arab World: Production,

Co-ordination, and Dissemination. Meta, 30(2), 155-160.

https://doi.org/10.7202/004142ar d'utilisation que vous pouvez consulter en ligne. 


\section{ÉTUDES TERMINOLOGIQUES ET LINGUISTIQUES}

\section{SCIENTIFIC TERMINOLOGY IN THE ARAB WORLD : PRODUCTION, CO-ORDINATION, AND DISSEMINATION}

A look at the problems of Arabization of science and the transfer of technology to the Arab World would reveal many types of linguistic obstacles. Some of these problems are related to terminology and translation. Others are related to Arabization of the teaching of scientific and technical subjects in the institutions of higher education, availability of Arabic references, and maintenance of contact with literature published in foreign languages.

In this paper I will try to concentrate on the discussion of one of these obstacles, terminology, its production, co-ordination and dissemination.

\section{TERMINOLOGY}

It is estimated that terminology is responsible for 40 to $60 \%$ of the technical translator's errors, and that search for the proper terms takes up about $50 \%$ of his valuable time (Krollman 1978). It is no wonder then that any agency involved in the Arabization of scientific data has to resolve the issues of terminology before anything else.

\section{TERMINOLOGY PRODUCTION}

A close study of the situation in the Arab World would reveal that there are many agencies involved in terminology making, officially or unofficially. Following are some of these agencies.

\subsection{The Academies}

To date there are four national academies in the Arab World.

The Arabic Language Academy, Damascus

Historically this is the oldest academy in the Arab world. It was established in 1919 under the name : The Syrian Scientific Academy. It has since been actively involved in terminology Arabization, among other activities of the Academy, which is not fully devoted to the issue of terminology. But, unfortunately, the Academy does not have any specific procedures for the Arabization of terminology, nor has it published any glossaries or dictionaries in independent forms, according to its president Dr. Husni Sabah, a professor of Medicine (Personal communication).

Arabic Language Academy, Cairo

The Cairo Academy was the second active academy, which was established in 1932, under the name : The Royal Arabic Language Academy. It has since been very 
active in the field of Arabic terminology making. The first issue of the Academy Bulletin was published in 1934 (Al-Jabbouri 1965 : 16). The Cairo Academy has very sophisticated procedures in processing the new terms beginning from subject specialties through to the annual "General Conference", when the new terms are given the blessings of the Academy.

\section{The Iraqi Scientific Academy}

The Academy was established in 1947 under the same name. In 1939 the old Academy was abolished, and a new one established with the same name, but with a new constitution and organization (Al-Jabbouri 1965 : 99ff). Many permanent committees were set up. The three committees of interest to us in this paper are : the Committee for Encouragement of Writing, Publication and Translation, the Dictionaries Committee, and the Scientific Terminology Committee. The Iraqi Academy seems to have specific procedures for the coinage and adoption of new terminology.

\section{The Arabic Language Academy of Jordan}

The Jordanian Academy is the newest of the Academies, established in 1976. "The initiative for ALAJ came from the Jordan Committee for Arabization, Translation, and Publication..., a minor language-planning agency created within the Ministry of Education in 1961." (Ibrahim $1979: 1$ ) Though young in age the Jordanian Academy has been very active and well organized in the production of terminology as well as in the sponsorship of the translation and publication of scientific text-books.

\subsection{ALECSO's Bureau of the Coordination of Arabization in the Arab World}

Though the Bureau is a co-ordination agency it has been actively involved in the coinage of new terminology, mainly through the personal interest of its director, Professor Abdulaziz bin Abdullah.

\subsection{Research Institutes}

Many research institutes in the Arab World are involved in technical terminology recording and making. Among these institutes are the following :

\section{The Institute for Studies and Research for Arabization}

This Institute, which was established by the Moroccan government in Rabat in the early 60 's, can be considered the most active in the field. We are told that it is has more than one million lexical cards in its files (Al-Habbaabi $1982: 272$ ). The Institute has also been actively involved in the coding of Arabic characters for computers.

\section{The Kuwait Research Institute}

Among the projects for the Kuwait Institute seems to be the compilation of scientific terms in certain specializations, such as Chemistry.

The Arab Development Institute, Tripoli, Libya, and Beirut

The production of the largest dictionary of science and technology in the Arab World has been sponsored by the said Institute in co-operation with McGraw-Hill publishers of New York. Two volumes of the projected four plus volumes are out. But the compilation has already been completed, according to professor Shukry Al-Fayasal, an editor of the dictionary (Personal communication).

\subsection{Pan-Arab Organizations}

Many pan-Arab organizations are also involved in the production of terminology in their fields of specialization and/or interest. Below we give mention to four of the most active ones. 


\section{ASMO (The Arab Standardization and Metrology Organization), Amman}

Since its establishment ASMO has been actively involved in Arabizing ISO terms as well as other terms related to its activities, in collaboration with its member organizations, such as SASO (the Saudi Arabian Standardization Organization). In fact, ASMO has its own Terminology Committee.

Arab Organization for Administration Sciences, Amman

This is another pan-Arab organization that has been actively sponsoring the production of technical terminology in its fields of interest. Among its published projects is the trilingual Unified Dictionary of Computer Terminology of 1982.

Arab Organization for Agricultural Development, Khartoum

No less than four trilingual dictionaries of Agriculture and allied fields have been compiled and published by the above Organization.

OAPEC (The Organization of Arab Petroleum Exporting Countries), Kuwait

Due to the nature of the Organization, and probably the fact that Arabic is the official language of OPEC, OAPEC has seen to it that Arabic is the official language of technical dictionaries of energy, oil and related fields. A couple of dictionaries have already been published.

\subsection{Pan-Arab Associations}

Besides the organizations mentioned above, there are many pan-Arab professional associations that have been involved in technical terminology making. Some of these associations have already published their work, such as the Arab Steel and Iron Association and the Association of Arab Physicians. Others are working on the compilation of specialized bi-or multilingual dictionaries or glossaries. Among the latter are : the Associations of Arab Chemists, Physicists and Mathematicians, Pharmacists, etc. (See Khalifa 1982 : 137-138)

\subsection{Publishers}

Though many publishers in the Arab World are involved in the publication of specialized and general dictionaries, two publishers deserve a special mention for their direct involvement in terminology making, either in-house or by consigning people to do it for them. These two publishers are :

Librairie du Liban, Beirut

This is the most active publisher in the field of dictionaries, especially bilingual ones. It even has a special dictionary department, which is responsible for the production and/or publication of the largest number of scientific dictionaries in the Middle East.

\section{Al-Ahram Establishment, Cairo}

This is the house responsible for the outstanding set of more than 15 technical dictionaries, which it sponsored and published in co-operation with the East German Edition Leipzig. Each dictionary has Arabic terms with their definitions and equivalents in English, French and German.

\subsection{Oil Companies}

The translation departments in the various oil companies working in the Arab World have also been very busy in technical terminology making, not only in oil industry but also in the fields of finance and administration. A typical example is the work prepared by Aramco in Dhahran. However, it seems that most of their work is prepared for in-house use mainly. 


\subsection{Universities}

In their attempt to Arabize technical and scientific education some Arab universities have set up 'Arabization Centers'. Three such universities known to the author are King Abdulaziz University in Jeddah and King Faisal University in Dammam, Saudi Arabia, and the University of Technology in Baghdad, Iraq. All seem to have a special interest in Engineering and allied fields. The King Abdulaziz University Center for Arabization of Technical Education has developed its own special procedures for the compilation and production of technical terms. It even has its own automated dictionary.

\subsection{Mass Communication Agencies}

Though these agencies, both governmental and private, do not claim to be terminology makers, it seems that the ad hoc terms coined everyday by their translators are the ones that reach the widest audience. For it is radio, television, newspapers and magazines that have the most contact with the masses, specialists and laymen alike.

\subsection{Individuals}

Individual efforts in terminology making can be seen in two areas of activity : (1) dictionary compilation and (2) ad hoc terms coined in the process of translation of technical material.

\subsection{Others}

Besides the agencies mentioned above, there are many others that are involved one way or another in the production of technical terms. Among these agencies are the standardization agencies in the Arab World, which have their own terminology ' committees' or departments.

\section{TERMINOLOGY CO-ORDINATION}

One of the most disturbing problems that faces the user of terminology in Arabic is the presence of different words for the same concept, which is also a source of confusion to the reader of technical writings. In an attempt to face this acute problem some agencies were established. Following is a brief account of some of these agencies.

\subsection{Pan-Arab Agencies}

Bureau for the co-ordination of Arabization in the Arab World (BCAAW)

This is the Bureau established in Rabat in 1961 by the ALECSO (Arab League Educational, Cultural, and Scientific Organization). The Bureau has been trying to do its job through various Arabization conferences held periodically in different Arab countries, its official Bulletin Allisaan Al-Arabi, and its occasional trilingual glossaries. It has a board whose members are eminent scholars representing different Arab nations. The Association of Arab Academies, Cairo

In theory at least, this Association is supposed to co-ordinate activities of the four member Academies. But little is known of any of its activities in the area of terminology, or any other area for that matter.

\section{ASMO}

We have already mentioned that this pan-Arab Organization has as one of its main functions the co-ordination of standardization and metrology related activities among its members, including the compilation of terminology. 


\section{Others}

Mention has already been made of the various pan-Arab associations involved in the production of technical terminology. By their pan-Arabic nature they are also agents of co-ordination in their respective fields, at least.

\subsection{National Agencies}

The problem of co-ordination and unification of terminology does not seem to be restricted to international activities in the Arab world. For the problem persists even on the national level. A case in point is the production of terminology in projects sponsored by the Syrian government. In Damascus alone, there are three higher education agencies that are involved in terminology making, one way or another. There is first the Arabic Language Academy, which is theoretically supposed to oversee the terminology production activities. But the ministry of Higher Education has its own Department of Translation which sponsors the translation of scientific books into Arabic. In the absence of official glossaries, each translator chooses and/or coins his own Arabic terms. $\mathrm{He}$ is required only to append a bilingual glossary to his translated work, hopefully to be used by reviewers to ensure internal consistency of terminology. The third agency which sponsors the translation of scientific works is the University of Damascus. Naturally, the process of translation automatically means decisions related to terminology choice and coinage. Such an arrangement necessarily leads to lack of unification, at least of new terminology.

Another notorious example of the lack of coordination is that of the BCAAW and IERA in Rabat (see above). Both agencies are located in Rabat, one being a pan-Arab and the other a national one. The discrepancies or lack of co-ordination between them is common knowledge. The problem of co-ordination, in my opinion, is no less acute in Cairo, where again many agencies, official or private, are involved in terminology making, all being under no obligation to co-ordinate with or follow the Academy, in practice at least.

To summarize, theoretically, there are many national agencies for the coordination of terminology activities, such as the Academies in Amman, Baghdad, Cairo and Damascus. However, in practice it seems that the lack of co-ordination is the unfortunate rule. This is true even in countries which have Academies and/or standardization organizations.

\section{DISSEMINATION OF TERMINOLOGY}

Different methods are being followed by various individuals and organizations for the dissemination of terminology in the Arab World :

\subsection{Dictionaries}

This is the most common and practical means of dissemination. Technical dictionaries have been published by some academies, notably the Academy in Cairo, and various organizations, such as the Arab Agriculture Development Organization and OAPEC, research institutes such as the Kuwait Research Institute and the Arab Development Institute, besides commercial publishers and individuals.

Dictionaries could be monolingual, bi- or multilingual. Some bilingual and multilingual dictionaries give definitions, such as the technical dictionaries published by AlAhram. Others only give the equivalent terms, such as the Unified Medical Dictionary.

\subsection{Glossaries}

By a glossary we mean a short or long list of specialized foreign terms along with their Arabic equivalents. Glossaries are published in three different ways : 
Mini dictionaries, in the form of booklets

BACAAW, the Jordanian Academy and the Iraqi Academy have published many such glossaries.

Aramco, on the other hand, has loose leaf glossaries for in-house use.

Sections of periodical bulletins or magazines

This is the common practice followed by all the Academies. BCAAW has a regular section of its bulletin Al-lisan al-Arabi devoted to proposed terminology in various fields. Recently, many specialist magazines in the Arab world have small sections of their magazines devoted to bilingual glossaries for terms in their fields of specialization. Typical examples are the Saudi Computer World and the Gulf $T V$, quarterly magazine of the Gulfvision.

\subsection{Appendixes}

As mentioned earlier all the books translated under the sponsorship of the Syrian Ministry of Higher Education are required to have glossaries appended to them. Besides, in different countries many authors in new disciplines (e.g. Modern Linguistics) often append glossaries of technical terms in their publications.

MAHMOUd ESMAIL SIENY

\section{REFERENCES}

AMMAR, Ahmad (1961) : "A Call to Observe a Clear Plan in Coining Medical Terms", in the Proceedings of the Arabic Language Academy Conference (1969-1961), Cairo, Arabic Language Academy, pp. 45-56. BINABDALLAH, Abdul-Aziz (1982) : "Arabization Institutions in the Arab World", in Markaz diraasaat al-wihdah al-arabiyyah (1982), pp. 113-129.

BINABDALLA, Abdul-Aziz (1975) : Arabization and the Future of Arabic, Cairo, The Institute for Arabic Research and Studies.

DIMASHQIYYAH, Aff (1982) : "The Instruments of Arabization from a Unificational Point of View", in Markaz diraasaat al-wihdah al-Arabiyya (1982), pp. 407-418.

FAHMI, Hasan (1961) : Source Book for the Arabization of Scientific, Technical and Engineering Terminology, Cairo, Arabic Renaissance Bookshop.

AL-FILALI, Mustafa (1982) : "Towards a Strategy for Arabization in the Arab World", in MDWA (1982), pp. 467-479.

GHAZAL, Ahmad Lakhdar (1977) : The General Procedure for Arabization, Rabat, The Institute for Research and Studies for Arabization.

AL-HABAABI, Fatima (1982) : "An Evaluation of the Arabization Experience in Morocco", in MDWA (1982), pp. 269-274.

HAMZAAWI, Mohammad Rashad (1975) : "Unification of Terminology or the Unification of Culture", in al-Aadaab, vol. 23, no 2 .

IBRAHIM, Mahmoud (1979) : "Arabization of Humanities : Issues and Propositions", in the Bulletin of the Jordanian Arabic Language Academy, nos 5 and 6, pp. 43-66.

IBRAHIM, Mohammed Hasan (1979) : "The Arabic Language Academy of Jordan", in Language Planning Newsletter.

JABBOURI, Abdullah (1965): The Scientific Academy of Iraq, Baghdad, Al-Ani Press.

AL-KASIMI, Ali (1980) : "Problems of Arabization in the Arab World", in Al-Faisal, no 32 (January 1980), pp. $15-20$.

* N.B. with the exception of Ibrahim, M.H. (1979) all the references are written in Arabic. The titles given are my translations of the original titles. 
KHALIFA, Abdul-Karim (1982) : "Commerts on Binabdallah (1982)", in MDWA (1982), pp. 130-140. KHALIL, Hilmy (1980) : "Arabic and Linguistic Loans", in al-Majallah al-Arabiyyah, vol. 4, no 7, pp. 22-24 AL-KHATIB, Ahmad Sh. (1982) : "Procedures for Coining New Scientific Terms, with a Translation of Common Prefixes and Suffixes", in al-Lisan al-Arabi, vol. 19, Part I, pp. 37-66.

MADKOUR, Ibrahim (1974) : "The Yearly Outcome of the Arabic Language Academy : 2500 Scientific Terms", in al-Arabi, no 187.

MDWA (Markaz diraasaat al-wihdah al-Arabiyyah) (1982) : Arabization and its Role in Supporting Arabic Presence and Arab Unity (Papers and Discussions of the Symposium Organized by MDWA).

AL-QAISI, Kamal A. (1978) : "The Process of Arabization and its Requirements in the Scientific and Educational Areas", A paper given at the Conference on Arabization of Higher Education in the Arab World (4-7 March, 1978) in Baghdad.

AL-SALEH, Subhi (1982) : "Evaluation of Arabization in Eastern Arab Countries", in MDWA (1982), pp. $201-209$.

AL-SALEH, Subhi (1975) : "Arabic and Arabization", al-Aadaab, vol. 23, no 2.

AL-SAMRAH, Mahmoud (1982) : "The Expression of the Jordanian Arabic Language Academy in the Arabization of Sciences", in the JALA Bulletin, vol. 5, nos 15 and 16, pp. 96-101.

AL-SAYYADI, Mohammad Al-Munji (1982) : Arabization and its Co-ordination in the Arab World, $2^{\text {nd }}$ ed., Beirout, Center for Arab Unity Studies (MDWA).

SHANIN, Abdul-Sabour (1983) : Arabic, the Language of Science and Technology, Khobar, Dar al-Islah for Printing, Publication and Distribution.

SHAHIN, Tawfiq (1980) : Factors of Developing Arabic, Cairo, Wahba Bookshop.

AL-SHIHAABI, al-Amir Mustafa (1955) : Scientific Terminology in Arabic in Old and Recent Times, Cairo, The Institute for Arabic Research and Studies.

SU'AIDAN, Ahmad Salim (1979) : "Towards the Arabization of University Education in Natural Sciences : Problems and Solutions", in the Bulletin of the Jordanian Arabic Language Academy, vol. 2, nos 5 and 6, pp. 30-42. 